\title{
Marine dispersal determines the genetic population structure of migratory stream fauna of Puerto Rico: evidence for island-scale population recovery processes
}

\author{
Benjamin D. Cook ${ }^{1}$ AND Sofie Bernays ${ }^{2}$ \\ Australian Rivers Institute, Griffith University, Nathan, Queensland, Australia 4111
}

\author{
Catherine M. Pringle ${ }^{3}$ \\ Odum School of Ecology, University of Georgia, Athens, Georgia 30602 USA \\ Jane M. Hughes ${ }^{4}$ \\ Australian Rivers Institute, Griffith University, Nathan, Queensland, Australia 4111
}

\begin{abstract}
Various components of island stream faunas, including caridean shrimps, fish, and gastropods, undertake obligate amphidromous migration, whereby larvae are released in upstream freshwater reaches, drift downstream to estuaries or marine waters, then migrate upstream as postlarvae to freshwater adult habitats. Longitudinal migration from estuaries to headwaters is well documented for many amphidromous species, but the degree of among-river marine dispersal is poorly known for most species. We need better understanding of the potential for marine dispersal in population processes of amphidromous species, particularly recolonization and population recovery in impacted lotic systems, such as those on Puerto Rico, because some theories of dispersal for species with marine larvae predict high rates of self-recruitment. We tested population genetic predictions for widespread marine larval dispersal and self-recruitment to the natal river for 11 amphidromous species, including shrimps, fish, and a gastropod, in Puerto Rico. Population genetic analysis of mitochondrial DNA data showed high rates of gene flow among rivers and indicated that marine dispersal determines the population genetic structure of all 11 species. Difficulty in recruiting to oceanic currents promotes closed population structures in some marine species, but larvae of amphidromous species entrained in downstream river flow might be delivered more readily to ocean currents. Population recovery processes occurred at the island scale rather than at the river scale, but further studies are needed to identify whether population recovery processes are likely at larger spatial scales (e.g., among islands). River management strategies should maintain environmental flows that allow larval export, maintain longitudinal dispersal pathways over dam spillways and via subterranean passages, and maintain open and healthy estuaries.
\end{abstract}

Key words: amphidromy, environmental flow, freshwater-marine connectivity, larval dispersal, larval duration.

Various components of island stream faunas, including some caridean shrimps, fish, and gastropods, undertake obligate amphidromous migration, whereby larvae are released in upstream freshwater reaches, drift downstream to estuaries or marine waters, then migrate upstream as postlarvae to freshwater adult habitats (Myers 1949, McDowall

\footnotetext{
${ }^{1}$ E-mail addresses: ben.cook@griffith.edu.au

2 s.bernays@griffith.edu.au

3 cpringle@uga.edu

4 jane.hughes@griffith.edu.au
}

2004, 2007). This life history allows individuals to exploit resources in both marine and freshwaters at different times in their life cycle, promotes the evolution of widespread distributional ranges in most amphidromous species, and allows species to recolonize islands following defaunation by disturbances and periods of freshwater scarcity over evolutionary time (Benstead et al. 2000, McDowall 2004, Covich 2006). Thus, lotic communities on oceanic islands tend to contain a greater proportion of amphidromous species than do communities on islands recently connected by land bridges or on continents where 
seaward migration is constrained by large distances between larval and adult habitats and relatively slow average water velocities in comparison to island rivers (Iguchi 2007). Amphidromy represents an ecological link between island rivers and receiving coastal waters (Benstead et al. 2000) and a mechanism of range expansion over evolutionary timescales (Fièvet 1998, Page et al. 2005, 2008), but the degree to which populations of amphidromous species are connected by marine dispersal and gene flow among rivers (and other geographic scales, e.g., among islands) on contemporary timescales is poorly known for most species (Holmquist et al. 1998, Covich 2006).

Puerto Rico has long been a model system for ecological studies, including stream ecology (e.g., Pringle et al. 1999, Crowl et al. 2001, Blanco and Scatena 2006). In particular, the key roles played by caridean shrimps in regulating benthic algal growth and rates of organic matter decomposition have emerged (Pringle et al. 1993, 1999, Pringle 1996, March et al. 2001, Crowl et al. 2001), as has the importance of maintaining hydrologic connectivity from river mouths to headwater streams for local persistence of amphidromous fauna (Pringle 1997, Benstead et al. 2000, Blanco and Scatena 2006, Crook et al. 2009). Loss of longitudinal connectivity between headwater streams and downstream estuaries via dam construction, sand sedimentation, or water withdrawal greatly diminishes connectivity between larval and adult habitats and leads to localized loss of amphidromous species and their roles in key ecosystem processes with consequences for the ecological health of benthic communities (Greathouse et al. 2006, Crook et al. 2009). In many cases, reversing degradation of lotic habitats in Puerto Rico requires restoration of hydrologic connectivity from river mouths to headwaters (Pringle 1997, Greathouse et al. 2006). However, responses by stream biota to ecosystem restoration are constrained by various factors (Bond and Lake 2003), and reinstatement of hydrologic connectivity might not translate directly into population recovery if recolonization from refugial populations is constrained by stream architecture or dispersal traits (Cook et al. 2007a, Hughes 2007).

Recently, 5 species of amphidromous shrimp from Puerto Rico were shown to have continuous population genetic structures among regions and rivers of Puerto Rico, a result indicating that these species and their ecological functions could become reestablished rapidly via marine larval dispersal if hydrologic connectivity were restored (Cook et al. 2008a). However, whether other amphidromous species, including other shrimps, fish, and gastropods, in Puerto Rico have similar abilities for oceanic dispersal and recolo- nization among rivers at the island scale is unknown. Some theories of dispersal for species with marine larvae predict high rates of self-recruitment because the effects of diffusion, mortality, and scarce adult habitat (i.e., lotic systems in the case of amphidromous species) would act as strong selection pressures to remain in the natal habitat (Cowen et al. 2000, Strathmann et al. 2002). We tested population genetic predictions for widespread marine larval dispersal and self-recruitment to the natal river, respectively, for 11 amphidromous species in Puerto Rico. If larvae of these species could disperse widely through marine habitats, we would expect no genetic substructure among populations from different rivers or marine regions in Puerto Rico and no signatures of isolation-by-distance (IBD) in the genetic data. IBD is a population pattern that reflects small-scale, stepping-stone dispersal among nearby habitats, and it is indicated by a significant correlation between interpopulation genetic differentiation and geographic distance. If amphidromous biota could disperse widely via the ocean, we would expect that genetic differentiation would be small and nonsignificant among both geographically proximate and distant habitats (i.e., interpopulation dispersal would not reflect a stepping-stone pattern). In contrast, if the larvae of these species were retained in the natal estuary or had high rates of self-recruitment, we would expect significant genetic subdivision among regions and among rivers within regions and possibly significant patterns of IBD caused by low rates of imperfect natal homing. Last, if larvae of these species could disperse only short distances via marine habitats, we would expect genetic substructure among regions, but not among rivers within regions, and significant IBD in the data. We discuss implications of our results for river management and lotic ecosystem restoration on the island.

\section{Methods}

The sampling design was the same as that of an earlier study (Cook et al. 2008a) and included 3 marine regions (Atlantic Ocean, Mona Passage, and Caribbean Sea), each with 3 rivers (Fig. 1). Not all species were represented in all rivers, but at least 2 regions were sampled for all species, and most species were sampled in 3 regional areas. Thus, a broad geographical area was sampled for each species (Table 1). Specimens were sampled nondestructively where possible (e.g., a leg was taken from shrimps and fin clips from gobies, and the individuals were released otherwise unharmed), although whole juveniles and snails were taken. Our study incorporated mitochondrial deoxyribonucleic acid (mtDNA) sequence data for 11 amphidromous species, 5 shrimps 


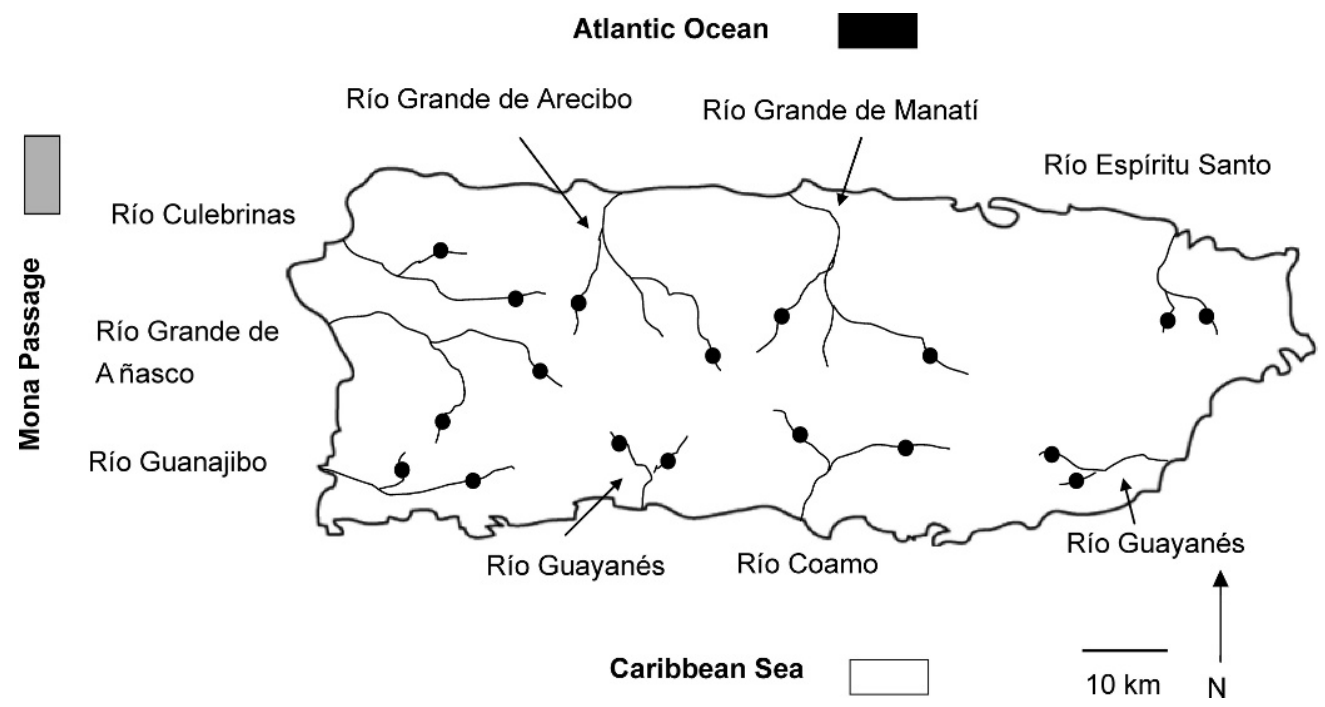

FIG. 1. Sampling locations in Puerto Rico. Shadings indicating marine regions are used in Fig. 2 to show regional distribution of haplotypes.

from Cook et al. (2008a), and an additional 6 species, including shrimps, fish, and a snail (Table 1). Sequences of the cytochrome c subunit I (COI) mtDNA gene were amplified, aligned, and edited for the invertebrates as described in Cook et al. (2008a), except the following primers were used for the snail, Neritina virginea (Neritidae): NVCOI-F, GGAAACTGATTGGTGCCTCTAATGC, and NVCOI-R, ACCCCCTCCTGCTGGATC (optimal annealing temperature $=55^{\circ} \mathrm{C}$ ). Aligned and edited fragments of the ATPase 6 and 8 mtDNA gene for the gobiid fish were obtained as described in Cook et al. (2007b).

Haplotype $(h)$ and nucleotide $(\pi)$ diversity and mean pairwise nucleotide differences $(k)$ were calculated in Arlequin version 2.0 (Schneider et al. 2000) to obtain measures of molecular diversity in each species. Haplotype networks were constructed using TCS version 1.18 (Clement et al. 2000) to show the genealogical relationships of the haplotypes and their geographic distribution. Population genetic structure was examined using analysis of molecular variance (AMOVA; Excoffier et al. 1992) according to the sampled hierarchy (i.e., among regions, among rivers within regions, and within rivers) as implemented in Arlequin with $\Phi$ indices, which incorporate both haplotype frequency and divergence. AMOVA assessed the significance of spatial genetic variation using 10,000 permutations of the observed genotypes. The relationship between pairwise $\Phi_{\mathrm{ST}}$ among rivers and geographic distance (shortest coastline distance among river mouths) was tested with Mantel tests (Mantel 1967) in PRIMER version 5.2.8 (Clarke and Gorley 2001) with 5000 permutations.

\section{Results}

Measures of molecular diversity were much lower for Atya lanipes and Micratya poeyi than for all other taxa (Table 1). Patterns of molecular diversity were reflected in the haplotype networks. Atya lanipes (Fig. 2A) and Mi. poeyi (Fig. 2F) each had star phylogenetic patterns composed only of closely related haplotypes, whereas all other taxa had more complex networks containing many closely related and more distantly related haplotypes (Fig. 2B-E, G$\mathrm{K})$. However, no networks had a geographical pattern in the distribution of haplotypes, and both internal and tip haplotypes (when they were represented in the sample by $>1$ individual) typically were distributed among regions. This lack of geographic population structure also was reflected in AMOVA results, which showed no genetic population structure at any scales of the hierarchy for most species (Table 2). Although no genetic differentiation was found at the largest scale of the analysis for any species (i.e., among regions), 3 species, Macrobrachium faustinum, Mi. poeyi, and Sicydium buscki, showed significant differentiation among rivers within regions (Table 2). All Mantel tests were nonsignificant (Table 2), a result indicating that genetic differentiation was not correlated with geographical distance in any species.

\section{Discussion}

Our study extends the results of an earlier study (Cook et al. 2008a) by showing genetic connectivity among rivers in amphidromous species throughout Puerto Rico. Therefore, our results indicate that 
TABLE 1. Sample and fragment information and measures of molecular diversity for each species. GGD = global geographic distribution, $\mathrm{GA}=$ Greater Antilles, $\mathrm{CAC}=$ Central America Caribbean (including the Greater and Lesser Antilles), $\mathrm{CAP}=$ Central American Pacific, SAA = South American Atlantic, SAP = South American Pacific, WA $=$ West Africa, $N=$ total number of individuals/rivers/regions sampled, $\mathrm{bp}=$ number of mitochondrial deoxyribonucleic acid bases used in analyses, $h=$ haplotype diversity, $\pi=$ nucleotide diversity, $k=$ average number of pairwise differences. Asterisk $\left({ }^{*}\right)$ indicates analyses from Cook et al. (2008a).

\begin{tabular}{|c|c|c|c|c|c|c|c|c|}
\hline Species & GGD & $N$ & $\mathrm{bp}$ & $h$ & $\pi$ & $k$ & $\begin{array}{l}\text { No. unique } \\
\text { haplotypes }\end{array}$ & $\begin{array}{c}\text { Genbank } \\
\text { accession } \\
\text { numbers }\end{array}$ \\
\hline Atya lanipes* & GA & $185 / 8 / 3$ & 773 & $0.352 \pm 0.003$ & $0.0005 \pm 0.0005$ & $0.421 \pm 0.385$ & 32 & $\begin{array}{l}\text { EU005053- } \\
\text { EU005083 }\end{array}$ \\
\hline Atya scabra* & $\begin{array}{r}\text { CAC, CAP, } \\
\text { SAA, WA }\end{array}$ & $225 / 9 / 3$ & 596 & $0.986 \pm 0.004$ & $0.013 \pm 0.007$ & $7.714 \pm 3.608$ & 129 & $\begin{array}{r}\text { EU005084- } \\
\text { EU005224 }\end{array}$ \\
\hline Micratya poeyi & CAC & $52 / 5 / 3$ & 775 & $0.494 \pm 0.086$ & $0.0008 \pm 0.0007$ & $0.639 \pm 0.506$ & 12 & $\begin{array}{c}\text { FJ348779- } \\
\text { FJ348827 }\end{array}$ \\
\hline Micratya sp. & $?$ & $104 / 5 / 3$ & 756 & $0.935 \pm 0.014$ & $0.009 \pm 0.005$ & $6.584 \pm 3.136$ & 41 & $\begin{array}{c}\text { FJ348828- } \\
\text { FJ348931 }\end{array}$ \\
\hline \multicolumn{9}{|c|}{ Crustacea:Decapoda:Xiphocarididae (long-faced shrimp) } \\
\hline $\begin{array}{c}\text { Macrobrachium } \\
\text { faustinum }^{*}\end{array}$ & CAC & $71 / 7 / 3$ & 708 & $0.731 \pm 0.060$ & $0.002 \pm 0.001$ & $1.356 \pm 0.853$ & 34 & $\begin{array}{l}\text { EU005001- } \\
\text { EU005035 }\end{array}$ \\
\hline \multicolumn{9}{|c|}{ Actinopterygii:Perciformes:Gobiidae (gobies) } \\
\hline Sicydium buscki & CAC, SAA & $80 / 5 / 2$ & 657 & $0.975 \pm 0.008$ & $0.005 \pm 0.003$ & $3.524 \pm 1.813$ & 50 & $\begin{array}{c}\text { FJ349016- } \\
\text { FJ349095 }\end{array}$ \\
\hline Sicydium punctatum & CAC, SAA & $34 / 4 / 3$ & 657 & $0.856 \pm 0.059$ & $0.005 \pm 0.003$ & $3.077 \pm 1.640$ & 19 & $\begin{array}{c}\text { FJ348742- } \\
\text { FJ348775 }\end{array}$ \\
\hline Sicydium sp. & ? & $40 / 5 / 2$ & 657 & $0.963 \pm 0.016$ & $0.007 \pm 0.004$ & $4.774 \pm 2.383$ & 26 & $\begin{array}{l}\text { FJ348976- } \\
\text { FJ349015 }\end{array}$ \\
\hline \multicolumn{9}{|c|}{ Mollusca:Gastropoda:Neritidae (freshwater snail) } \\
\hline Neritina virginea & $\begin{array}{l}\text { CAC, SAA, } \\
\text { CAP? }\end{array}$ & $44 / 2 / 2$ & 354 & $0.910 \pm 0.030$ & $0.010 \pm 0.006$ & $3.629 \pm 1.875$ & 24 & $\begin{array}{c}\text { FJ348932- } \\
\text { FJ348975 }\end{array}$ \\
\hline
\end{tabular}

amphidromous species have well-developed abilities for marine dispersal at the island scale. Our results support findings of an allozyme study that found panmixia among rivers in Guadeloupe (Lesser Antilles) for Atya innocous (Fièvet and Eppe 2002), another allozyme study that found panmixia among 8 riverine populations of the goby, Sicyophterus lagocephalus, in La Réunion Island (Berrebi et al. 2005), and a phylogeographic study that found high rates of gene flow for the amphidromous fish, Galaxias maculatus, in New Zealand (Waters et al. 2000). One of the species considered in our study, Xiphocaris elongata, has no significant genetic population structuring among islands of the Greater Antilles (Reuschel 2008), a result suggesting that amphidromy facilitates ongoing oceanic dispersal at very large geographic scales for some species. A similar absence of phylogeographic structuring was found in amphidromous fish, shrimps, and gastropods among islands of the Hawaiian archipelago (Chubb et al. 1998, Bebler and Foltz 2004). Some catadromous species (i.e., freshwater species in which the adult migrates to estuaries for reproduction) show a similar absence of phylogeographic structuring over large spatial scales, although large-scale patterns of gene flow among riverine populations tend to occur in a stepping-stone fashion for some catadromous species, such as Australian bass (Macquaria novemaculeata; Chenoweth and Hughes 1997).

In striking contrast, Mona Passage represents a long-term phylogeographic break between Puerto Rico and the Dominican Republic for populations of coral reef gobies (genus Elacatinus; Taylor and Hellberg 2006). Thus, diadromous species appear to 

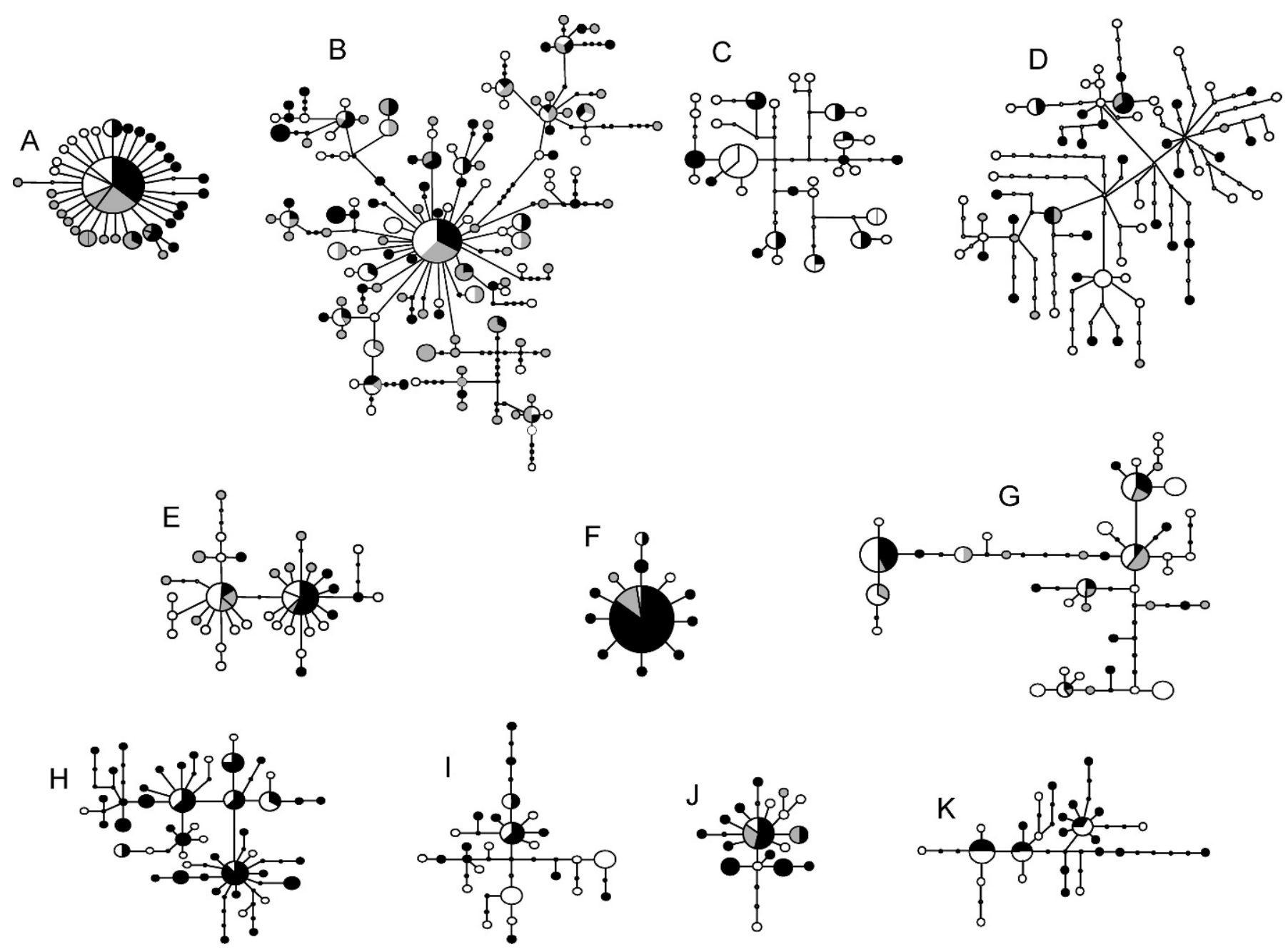

Fig. 2. Haplotype networks for 11 amphidromous species from Puerto Rico: Atya lanipes (A), Atya scabra (B), Atya innocous (C), Xiphocaris elongata (D), Macrobrachium faustinum (E), Micratya poeyi (F), Micratya sp. (G), Sicydium buscki (H), Sicydium punctatum (I), Sicydium sp. (J), and Neritina virginea $(\mathrm{K})$. Each circle represents a haplotype. The size of the circle represents the relative frequency of the haplotype in the sample, and the colors represent the region where each haplotype was found (see Fig. 1).

have better abilities for marine dispersal than do some marine species. However, at very large spatial scales, such as between continents, rare marine dispersal by amphidromous species might occur but be insufficient to prevent genetic differentiation between continents. For example, dispersal between highly differentiated Australian and New Zealand populations of G. maculatus is rare (Waters et al. 2000), although Australian and New Zealand populations of the catadromous eel, Anguilla australis, are genetically continuous (Dijkstra and Jellyman 1999). In contrast to trans-Tasman gene flow patterns in these diadromous species, a phylogeographic study of marine gastropods (genera Austrolittorina and Scutus) found no evidence for contemporary or historical gene flow between Australian and New Zealand populations (Waters et al. 2007), a result indicating another case in which diadromous species have better abilities for long-range marine dispersal than do some marine species. It would be interesting to determine whether populations of Atya scabra from the Caribbean (western Atlantic Ocean) and the west coast of Africa, including the Cape Verde Islands (eastern Atlantic Ocean), are connected by intercontinental oceanic dispersal.

The larvae of some euryhaline species use retention strategies to remain in the estuary of the natal river. The degree of retention usually is influenced by estuary or embayment morphology and rates of water exchange because few species have purely behavioral larval retention strategies (Bilton et al. 2002), although such strategies have been reported for the euryhaline rainbow smelt, Osmerus mordax (Bradbury et al. 2008). Indeed, most euryhaline species use larval export 
TABLE 2. Results of tests for geographic population genetic structure based on $\Phi$ indices, including analysis of molecular variance (AMOVA) and Mantel tests. Neritina virginea was sampled from only 2 rivers. Thus, neither a Mantel test nor a full hierarchical AMOVA could be implemented (only pairwise $\Phi_{\mathrm{ST}}$ among the 2 rivers could be calculated). $\Phi_{\mathrm{CT}}=$ differentiation among regions, $\Phi_{\mathrm{SC}}=$ differentiation among rivers within regions, $\Phi_{\mathrm{ST}}=$ variance within rivers. $p$ values are shown in parentheses, and significant results are indicated in bold. Asterisk (*) indicates analyses from Cook et al. (2008a).

\begin{tabular}{|c|c|c|c|c|}
\hline Species & \multicolumn{3}{|c|}{ AMOVA } & Mantel test $\rho$ \\
\hline Atya lanipes* & $0.003(0.364)$ & $-0.004(0.644)$ & $-0.004(0.768)$ & $0.298(0.096)$ \\
\hline Atya scabra* & $0.002(0.330)$ & $-0.002(0.536)$ & $0.0002(0.465)$ & $0.072(0.335)$ \\
\hline Atya innocous* & $0.011(0.247)$ & $-0.370(0.806)$ & $-0.260(0.905)$ & $0.500(0.498)$ \\
\hline Xphocaris elongata* & $-0.003(0.640)$ & $-0.009(0.817)$ & $-0.011(0.904)$ & $-0.943(1.000)$ \\
\hline Macrobrachium faustinum* & $-0.017(0.787)$ & $0.040(0.027)$ & $0.024(0.079)$ & $0.073(0.409)$ \\
\hline Sicydium buscki & $-0.061(0.599)$ & $0.105(0.002)$ & $0.050(<0.001)$ & $-0.580(0.962)$ \\
\hline Sicydium punctatum & $-0.065(0.667)$ & $0.081(1.000)$ & $0.021(0.194)$ & $0.500(0.497)$ \\
\hline Sicydium sp. & $0.028(0.251)$ & $-0.035(0.251)$ & $0.007(0.656)$ & $-1.000(1.000)$ \\
\hline Neritina virginea & - & - & $-0.012(0.581)$ & - \\
\hline
\end{tabular}

strategies, whereby larvae are flushed rapidly into the sea (Bilton et al. 2002). For example, larval hatch in sicydiine gobies occurs at a very early ontogenetic stage. Early hatch expedites migration and increases survival because yolk supplies are maintained during downstream drift, thereby minimizing mortality by starvation (McDowall 2009). However, some behavioral strategies, including negative phototaxis (i.e., descent from surface water layers in daytime vertical migration to avoid strong illumination), used by larvae of some amphidromous gobies, such as Rhinogobius spp. in Japan, represent constraints to the seaward migration of drifting larvae (Iguchi 2007). Similar diel patterns of larval drift (i.e., nocturnaldominated larval drift) have been reported as a predator-avoidance strategy for amphidromous shrimps in Puerto Rico (March et al. 1998) and Central America (Ramirez and Pringle 1999, 2001). However, vertical (directional) migration by drifting larvae is overcome by strong water velocity, such as for rivers on islands (Iguchi 2007); thus, peak discharges and strong water velocities ensure larval export despite intrinsic larval tendencies to descend to avoid strong illumination or predators. This result highlights the importance of water flow for export of amphidromous larvae and is one explanation for the relative scarcity of amphidromous species in large, slowflowing continental rivers (Iguchi 2007). Therefore, flow might be a factor associated with reported lifehistory transitions from amphidromous to nonmigratory, freshwater life-history strategies by some fish and shrimps inhabiting continents (McDowall 1997, Waters and Wallis 2001, Cook et al. 2006). The timing and magnitude of upstream migration by postlarvae of amphidromous species also is tightly linked to peak discharges in water flow (Benstead et al. 2000, Blanco and Scatena 2005). Therefore, damming island rivers and other alterations to the flow regime might reduce the ability of larvae of amphidromous species to recruit to the zooplankton of oceanic currents, thereby reducing the possibility that a given river will be a source of colonists for other rivers and constraining the return upstream migration of postlarvae to adult habitats. However, patterns of larval export and dispersal among populations for a given species might differ among hydrographic contexts (Bilton et al. 2002, Cook et al. 2007a). Thus, amphidromous species distributed across regions with contrasting embayment morphologies, tidal patterns, rates of water exchange between rivers and coastal waters, or nearshore oceanic currents might have different patterns of marine dispersal and population connectivity than those we report for Puerto Rican amphidromous species. Naturally closed or slowflowing systems might have naturally lower diversity of amphidromous species in comparison to nearby open systems, and these patterns should be considered in river management and ecosystem assessment programs (Parham 2005).

Larval duration is an important determinant of dispersal patterns in some marine nekton and benthos (e.g., Kyle and Boulding 2000, Grantham et al. 2003), but patterns of population structure in other marine species, such as reef gobies (genus Elacatinus; Taylor and Hellberg 2003) and squirrelfish (Family Holocentridae; Bowen et al. 2006), are not related to larval duration and probably reflect difficulty for larvae of nearshore or reef species to recruit to oceanic currents 
(Colin 2003). In contrast, the larvae of amphidromous species entrained in peak river flows might be delivered more readily to oceanic currents, where increased larval duration would be advantageous for widespread dispersal (e.g., Hoareau et al. 2007). Indeed, amphidromous shrimps of the Caribbean archipelago all have small eggs (Fièvet 1998), which is indicative of long larval duration. Xiphocaris elongate has high rates of gene flow among islands of the Greater Antilles (Reuschel 2008), a result indicating that larval duration is sufficiently long in this species to allow dispersal among islands. The Caribbean amphidromous gobies, Sicydium punctatum and Sicydium antillarum, also have very long larval durations in comparison with tropical marine gobies and coral reef fish (Bell et al. 1995), as do the Hawaiian amphidromous gobies, Lentipes concolor, Awaous guamensis, and Stenogobius hawaiiensis (Radtke et al. 1988, 2001). In contrast, caridean shrimps that penetrate upstream reaches of Central American continental rivers have larger egg size (Fièvet 1998), a result that is indicative of abbreviated larval development that minimizes larval export from high gradient streams (Hughes et al. 1995) or larval mortality by starvation associated with delayed larval export in river systems with long, slowflowing floodplain reaches (Iguchi 2007).

High rates of gene flow were shown for all species at the largest spatial scale of our study, but analyses for 3 species (M. faustinum, Mi. poeyi, and S. buscki) showed significant population genetic structuring at the 2 smallest geographic scales. These results probably represent nonequilibrium dynamics in population structure, similar to results reported for widely dispersing stream insects (Bunn and Hughes 1997), in which kin-structured founders promote the greatest genetic differentiation on the smallest spatial scale (Whitlock and McCauley 1990), and widespread fish in which any 1 sample might not reflect the overall genetic composition of the total population (Allendorf and Phelps 1981, Waples 1998). Extinction and recolonization, processes that dominate the biogeographic history of island stream biota (Covich 2006, Cook et al. 2008a), also promote nonequilibrium dynamics in population structure, whereby the largest component of genetic variation is partitioned over the smallest geographic scale (Whitlock and McCauley 1990). Thus, gene flow occurs among rivers in all amphidromous species, and nonequilibrium population structure promotes small-scale patchiness in genetic composition for some species. A similar pattern of patchiness in small-scale genetic population structure was temporally unstable among years for the widely dispersing, amphidromous goby, $S$. lagocephalus, in La Réunion Island (Berrebi et al. 2005).
Even small rates of gene flow can produce genetic homogeneity among geographic locations. Studies of some anadromous fish (i.e., marine species in which the adults migrate to freshwater reaches of rivers for reproduction) have shown that rare straying and imperfect natal homing can promote genetic continuity among demographically independent riverine populations (Campana and Thorrold 2001). Homing in anadromous fish fosters local adaptation, whereas infrequent straying has long-term evolutionary advantages (e.g., recolonization of defaunated habitats, genetic rescue). Thus, homing and straying are synergistic life-history traits that have adaptive associations over short and long temporal scales, respectively (McDowall 2001). Benstead et al. (2000) found multiple larval stages of shrimp species within estuaries, a result indicating that at least a proportion of the larvae develop to postlarval stages within estuaries. In contrast, the snail, N. virginea, is absent from rivers in which sand sedimentation has closed the estuary (Blanco and Scatena 2006), a result that indicates marine rather than estuarine larval development in this species. Thus, the relative adaptive association of natal retention and larval export, respectively, might differ among taxonomic groups (McDowall 2001).

Our study shows that the marine component of larval development and dispersal determines the genetic population structure of amphidromous species in Puerto Rico and indicates that population recovery processes probably occur at the island scale rather than the river scale, although further studies are needed to determine whether population recovery is likely at larger spatial scales (e.g., among islands). This result corroborates the findings of other population genetic and phylogeographic studies that have shown genetic continuity in amphidromous species both among rivers on an island or among islands within an archipelago (e.g., Chubb et al. 1998, Waters et al. 2000, Fièvet and Eppe 2002, Bebler and Foltz 2004, Berrebi et al. 2005, Cook et al. 2008a, Page et al. 2008). These molecular studies, in turn, support findings of biogeographic studies that have inferred good marine dispersal capabilities over evolutionary and ecological time scales (Fièvet 1998, McDowall 2004, 2007, Covich 2006) and indicate that amphidromous species probably will recolonize impacted stream habitat if longitudinal hydrologic connectivity is reinstated (Pringle 1997, Greathouse et al. 2006, Cook et al. 2008a, Crook et al. 2009). Biogeographic and population genetic studies have shown that some stream insects on oceanic islands can disperse effectively over large spatial scales (Kelly et al. 2001, Bass 2003), although other aquatic insects are geo- 
graphically restricted, island endemics (Englund 2008), indicating limited dispersal ability in these taxa. Contemporary dispersal in another group of Caribbean island freshwater endemics, freshwater crabs (genus Epilobocera), tends to be restricted to within river scales (Cook et al. 2008b).

We recommend use of river management strategies that maintain environmental flows to allow larval export and cues for postlarval upstream migration, maintain dispersal pathways over dam spillways (Greathouse et al. 2006) and via subterranean passages (Fièvet and Eppe 2002), maintain open and healthy estuaries (Blanco and Scatena 2006), and implement water abstraction and fishing practices that minimize mass mortality of drifting larvae and adult populations (Benstead et al. 1999, Greathouse et al. 2005). The importance of naturally closed or slow-flowing rivers that might contain comparably few amphidromous species also must be recognized by management authorities as a key driver of spatial freshwater biodiversity patterns among island rivers.

\section{Acknowledgements}

This research was funded by a Cooperative Agreement between the US Department of Agriculture (USDA) Forest Service's International Institute of Tropical Forestry (IITF) and the University of Georgia. It also was supported by the National Science Foundation Luquillo Long-Term Ecological Research grants DEB-0218039 and DEB-0620910 to IITF, the University of Puerto Rico, and the IITF USDA Forest Service, as part of the Long-Term Ecological Research Program in the Luquillo Experimental Forest. We thank the USDA Forest Service for permits to sample and for financial support and thank the Australian Rivers Institute, Griffith University, for additional financial support. Pablo Hernandez-Garcia and Katherine Smith helped during the sampling expedition, and H. Larson (Northern Territory Museum) helped identify juvenile gobies.

\section{Literature Cited}

Allendorf, F. W., And S. R. Phelps. 1981. Use of allelic frequencies to describe population structure. Canadian Journal of Fisheries and Aquatic Sciences 38:1507-1514.

BAss, D. 2003. A comparison of freshwater macroinvertebrate communities on small Caribbean islands. BioScience 53:1094-1100.

Bebler, M. H., AND D. W. Foltz. 2004. Genetic diversity in Hawaiian stream macroinvertebrates. Micronesia 37: 117-126.

Bell, K. N. I., P. Pepin, And J. A. Brown. 1995. Seasonal, inverse cycling of length and age-at-recruitment in the diadromous gobies, Sicydium punctatum and Sicydium antillarum, in Dominica, West Indies. Canadian Journal of Fisheries and Aquatic Sciences 52:1535-1545.

Benstead, J. P., J. G. March, and C. M. Pringle. 2000. Estuarine larval development and upstream post-larval migration of freshwater shrimps in two tropical rivers of Puerto Rico. Biotropica 32:545-548.

Benstead, J. P., J. G. March, C. M. Pringle, and F. N. Scatena. 1999. Effects of a low head dam and water abstraction on migratory stream fauna. Ecological Applications 9: 656-668.

Berrebi, P., G. Cattaneo-Berrebi, J.-F. Ricou, and T. Hoareau. 2005. Genetic homogeneity in eight freshwater populations of Sicyopterus lagocephalus, an amphidromous gobiid of La Réunion Island. Marine Biology 148:179-188.

Bilton, D. T., J. Paula, and J. D. D. Bishop. 2002. Dispersal, genetic differentiation and speciation in estuarine organisms. Estuarine, Coastal and Shelf Science 55: 937-952.

Blanco, J. F., and F. N. Scatena. 2005. Floods, habitat hydraulics and upstream migration of Neritina virginea (Gastropoda: Neritidae) in northeastern Puerto Rico. Caribbean Journal of Science 41:55-74.

Blanco, J. F., AND F. N. Scatena. 2006. Hierarchical contributions of river-ocean connectivity, water chemistry, hydraulics, and substrate to the distribution of diadromous snails in Puerto Rican streams. Journal of the North American Benthological Society 25:82-98.

BOND, N. R., AND P. S. LAKE. 2003. Local habitat restoration in streams: constraints on the effectiveness of restoration for stream biota. Ecological Management and Restoration 4:193-198.

Bowen, B. W., A. L. Bass, A. Muss, J. Carlin, and D. R. RoBERTSON. 2006. Phylogeography of two Atlantic squirrelfishes (Family Holocentridae): exploring links between pelagic larval duration and population connectivity. Marine Biology 149:899-913.

Bradbury, I. R., S. E. Campana, and P. Bentzen. 2008. Low genetic connectivity in an estuarine fish with pelagic larvae. Canadian Journal of Fisheries and Aquatic Sciences 65:147-158.

BunN, S. E., AND J. M. Hughes. 1997. Dispersal and recruitment in streams: evidence from genetic studies. Journal of the North American Benthological Society 16: 338-346.

Campana, S. E., and S. R. Thorrold. 2001. Otoliths, increments, and elements: keys to a comprehensive understanding of fish populations? Canadian Journal of Fisheries and Aquatic Sciences 58:30-38.

Chenoweth, S. F., And J. M. Hughes. 1997. Genetic population structure of the catadromous perciform: Macquaria novemaculeata (Percichthydae). Journal of Fish Biology 50:721-733.

Chubb, A. L., R. M. ZinK, And J. M. Fitzsimons. 1998. Patterns of mtDNA variation in Hawaiian freshwater fishes: the phylogeographic consequences of amphidromy. Journal of Heredity 89:8-16.

Clarke, K. R., And R. N. Gorley. 2001. PRIMER v 5.2.8: user manual/tutorial. PRIMER-E, Plymouth Marine Laboratory, Plymouth, UK. 
Clement, M., D. Posada, and K. Crandall. 2000. TCS: a computer program to estimate gene genealogies. Molecular Ecology 9:1657-1660.

Colin, P. L. 2003. Larvae retention: genes or oceanography? Science 300:1657.

Cook, B. D., A. M. Baker, T. J. Page, S. C. Grant, J. H. Fawcett, D. A. Hurwood, ANd J. M. Hughes. 2006. Biogeographic history of an Australian freshwater shrimp, Paratya australiensis (Atyidae): the role of life history transition in phylogeographic diversification. Molecular Ecology 15:1083-1093.

Cook, B. D., S. E. Bunn, And J. M. Hughes. 2007a. A comparative analysis of population structuring and genetic diversity in sympatric lineages of freshwater shrimp (Atyidae:Paratya): concerted or independent responses to hydrographic factors? Freshwater Biology 52:2156-2171.

CoOK, B. D., S. E. BunN, And J. M. Hughes. 2007b. Molecular genetic and stable isotope signatures reveal complementary patterns of population connectivity in the regionally vulnerable southern pygmy perch (Nannoperca australis). Biological Conservation 138:60-72.

Cook, B. D., C. M. Pringle, And J. M. Hughes. 2008a. Molecular evidence for sequential colonisation and taxon cycling in freshwater decapod shrimps on a Caribbean island. Molecular Ecology 17:1066-1075.

Cook, B. D., C. M. Pringle, and J. M. Hughes. 2008 b. Phylogeography of an island endemic, the Puerto Rican freshwater crab (Epilobocera sinuatifrons). Journal of Heredity 99:157-164.

Covich, A. P. 2006. Dispersal-limited biodiversity of tropical insular streams. Polish Journal of Ecology 54:523-547.

Cowen, R. K., K. M. M. Lwiza, S. Sponaugle, C. B. Paris, And D. B. Olsen. 2000. Connectivity of marine populations: open or closed? Science 287:857-859.

Crook, K. E., C. M. Pringle, and M. C. Freeman. 2009. A method to assess longitudinal riverine connectivity in tropical streams dominated by migratory biota. Aquatic Conservation (in press).

Crowl, T. A., W. H. McDowell, A. P. Covich, and S. L. JoHNSON. 2001. Freshwater shrimp effects on detrital processing and nutrients in a tropical headwater stream. Ecology 82:775-783.

DijKstra, C. H., and D. J. Jellyman. 1999. Is the subspecies classification of the freshwater eels Anguilla australis australis Richardson and A. a. schmidtii Phillips still valid? Marine and Freshwater Research 50:261-263.

EnGLund, R. A. 2008. Invasive species threats to native aquatic insect biodiversity and conservation measures in Hawai'i and French Polynesia. Journal of Insect Conservation 12:415-428.

Excoffier, L., P. E. Smouse, AND J. M. QuATtro. 1992. Analysis of molecular variance inferred from metric distances among DNA haplotypes: application to human mitochondrial DNA restriction data. Genetics 131:479-491.

FIÈvET, E. 1998. Distribution et capacities d'expansion des crevettes d'eau douce de la region caraibe exemple des genres Macrobrachium et Atya (Crustacea: Caridea). Biogeographica 74:1-22.
FIÈvet, E., AND R. EPPE. 2002. Genetic differentiation among populations of the amphidromous shrimp Atya innocous (Herbst) and obstacles to their upstream migration. Archiv für Hyrdobiologie 153:287-300.

Grantham, B. A., G. L. Eckert, and A. L. ShanKs. 2003. Dispersal potential of marine invertebrates in diverse habitats. Ecological Applications (Supplement) 13: S108-S116.

Greathouse, E. A., J. G. March, and C. M. Pringle. 2005. Recovery of a tropical stream after a harvest-related chlorine poisoning event. Freshwater Biology 50: 603-615.

Greathouse, E. A., C. M. Pringle, W. H. McDowell, and J. G. HolmQuist. 2006. Indirect upstream effects of dams: consequences of migratory consumer extirpation in Puerto Rico. Ecological Applications 16:339-352.

Hoareau, T. B., R. Lecomte-Finiger, H.-P. Grondin, C. ConAnd, AND P. Berrebi. 2007. Oceanic larval life of La Réunio 'bichiques', amphidromous gobiid post-larvae. Marine Ecology Progress Series 333:303-308.

Holmquist, J. G., J. M. Schmidt-Gengenbach, And B. B. YOSHIOKA. 1998. High dams and marine-freshwater linkages: effects on native and introduced fauna of the Caribbean. Conservation Biology 12:621-630.

Hughes, J. M. 2007. Constraints on recovery: using molecular methods to study connectivity of aquatic biota in rivers and streams. Freshwater Biology 52:616-631.

Hughes, J. M., S. E. Bunn, D. M. Kingston, and D. A. HuRwOOD. 1995. Genetic differentiation and dispersal among populations of Paratya australiensis (Atyidae) in rainforest streams in southeast Queensland, Australia. Journal of the North American Benthological Society 14: $158-173$.

IGUCHI, K. 2007. Limitations of early seaward migration success in amphidromous fishes. Bishop Museum Bulletin in Cultural and Environmental Studies 3:75-80.

Kelly, L. C., D. T. Bilton, and S. D. Rundle. 2001. Population structure and dispersal in the Canary Island caddisfly Mesophylax aspersus (Trichoptera, Limnephilidae). Heredity 86:370-377.

Kyle, C. J., And E. G. Boulding. 2000. Comparative population genetic structure of marine gastropods (Littorina spp.) with and without pelagic larval dispersal. Marine Biology 137:835-845.

Mantel, N. A. 1967. The detection of disease clustering and a generalised regression approach. Cancer Research 27: 209-220.

March, J. G., J. P. Benstead, C. M. Pringle, and M. W. Ruebel. 2001. Linking shrimp assemblages with rates of detrital processing along an elevational gradient in a tropical stream. Canadian Journal of Fisheries and Aquatic Sciences 58:470-478.

March, J. G., J. P. Benstead, C. M. Pringle, and F. N. Scatena. 1998. Migratory drift of larval freshwater shrimps in two tropical streams. Freshwater Biology 40:261-273.

McDowall, R. M. 1997. The evolution of diadromy in fishes (revisited) and its place in phylogenetic analysis. Reviews in Fish Biology and Fisheries 7:443-462. 
McDowall, R. M. 2001. Anadromy and homing: two lifehistory traits with adaptive synergies in salmonid fishes? Fish and Fisheries 2:78-85.

McDowall, R. M. 2004. Ancestry and amphidromy in island freshwater faunas. Fish and Fisheries 5:75-85.

McDowall, R. M. 2007. On amphidromy, a distinct form of diadromy in aquatic organisms. Fish and Fisheries 8: $1-13$.

McDowall, R. M. 2009. Early hatch: a strategy for safe downstream larval transport in amphidromous gobies. Reviews in Fish Biology and Fisheries 19:1-8.

MYeRs, M. J. 1949. Usage of anadromous, catadromous and allied terms for migratory fishes. Copeia 1949:89-97.

Page, T. J., A. M. Baker, B. D. CoOK, And J. M. Hughes. 2005. Historical transoceanic dispersal of a freshwater shrimp: the colonization of the South Pacific by the genus Paratya (Atyidae). Journal of Biogeography 32:581-593.

Page, T. J., B. D. CoOK, T. von Rintelen, K. von Rintelen, And J. M. Hughes. 2008. Evolutionary relationships of atyid shrimps imply both ancient Caribbean radiations and common marine dispersals. Journal of the North American Benthological Society 27:68-83.

Parham, J. E. 2005. Survey techniques for freshwater streams on oceanic islands: important design considerations for the PABITRA project. Pacific Science 59:283-291.

Pringle, C. M. 1996. Atyid shrimps (Decapoda: Atyidae) influence the spatial heterogeneity of algal communities over different scales in tropical montane streams, Puerto Rico. Freshwater Biology 35:125-140.

Pringle, C. M. 1997. Exploring how disturbance is transmitted upstream: going against the flow. Journal of the North American Benthological Society 16:425-438.

Pringle, C. M., G. A. Blake, A. P. Covich, K. M. Buzby, and A. FINLEY. 1993. Effects of omnivorous shrimp in a montane tropical stream: sediment removal, disturbance of sessile invertebrates and enhancement of understory algal biomass. Oecologia (Berlin) 93:1-11.

Pringle, C. M., N. Hemphill, W. H. McDowell, A. BednareK, AND J. G. MARCH. 1999. Linking species and ecosystems: different biotic assemblages cause interstream differences in organic matter. Ecology 80:1860-1872.

RadtKe, R. L., R. A. Kinzie, and S. D. Folson. 1988. Age at recruitment of Hawaiian freshwater gobies. Environmental Biology of Fishes 23:205-213.

RadtKe, R. L., R. A. KINZIE, AND D. J. Shafer. 2001. Temporal and spatial variation in length of larval life and size at settlement of the Hawaiian amphidromous goby Lentipes concolor. Journal of Fish Biology 59:928-938.

RamiReZ, A., AND C. M. PRINGLe. 1999. Invertebrate drift and benthic community structure dynamics in a lowland neotropical stream, Costa Rica. Hydrobiologia 386: 19-26.

Ramirez, A., And C. M. Pringle. 2001. Spatial and temporal patterns of invertebrate drift in streams draining a neotropical rainforest. Freshwater Biology 46:47-62.

Reuschel, S. 2008. Comparative phylogeographic studies of three marine and one amphidromous species clarifying the mechanisms of generation and maintenance of genetic diversity and identifying cryptic species. PhD Thesis, Regensburg University, Regensburg, Germany.

Schneider, S., J. Kuffer, D. Rossli, AND L. Excoffier. 2000. ARLEQUIN version 2.0: a software for population genetic data analysis. Genetics and Biometry Laboratory, Department of Anthropology and Ecology, University of Geneva, Geneva, Switzerland. (Available from: http://anthro.unige.ch/arlequin)

Strathmann, R. R., T. R. Hughes, A. M. Kuris, K. C. Lindeman, S. G. Morgan, J. M. Pandolfi, and R. R. WARNER. 2002. Evolution of local recruitment and its consequences for marine populations. Bulletin of Marine Science 70:377-396.

Taylor, M. S., and M. E. Hellberg. 2003. Genetic evidence for local retention of pelagic larvae in a Caribbean reef fish. Science 299:107-109.

Taylor, M. S., and M. E. Hellberg. 2006. Comparative phylogeography in a genus of coral reef fishes: biogeographic and genetic concordance in the Caribbean. Molecular Ecology 15:695-707.

WAPLES, R. S. 1998. Separating the wheat from the chaff: patterns of genetic differentiation in high gene flow species. Journal of Heredity 89:438-450.

Waters, J. M., L. H. Dijkstra, And G. P. Wallis. 2000. Biogeography of a southern hemisphere freshwater fish: how important is marine dispersal? Molecular Ecology 9:1815-1821.

Waters, J. M., G. A. McCulloch, and J. A. Eason. 2007. Marine biogeographical structure in two highly dispersive gastropods: implications for trans-Tasman dispersal. Journal of Biogeography 34:678-687.

Waters, J. M., And G. P. Wallis. 2001. Cladogenesis and loss of the marine life-history phase in galaxiid fishes (Osmeriformes: Galaxiidae). Evolution 55:587-597.

Whitlock, M. C., and D. E. McCauley. 1990. Some population genetic consequences of colony formation and extinction: genetic correlations within founding groups. Evolution 44:1717-1724.

Received: 16 January 2009 Accepted: 3 June 2009 